\title{
Does soil moisture overrule temperature dependence of soil respiration in Mediterranean riparian forests?
}

\author{
C. T. Chang ${ }^{1,2}$, S. Sabaté ${ }^{1,2}$, D. Sperlich ${ }^{1,2}$, S. Poblador $^{2}$, F. Sabater ${ }^{2}$, and C. Gracia ${ }^{1,2}$ \\ ${ }^{1}$ CREAF, Cerdanyola del Vallès, 08193, Spain \\ ${ }^{2}$ Departament d'Ecologia, Universitat de Barcelona (UB), 08028, Barcelona, Spain \\ Correspondence to: C. T. Chang (chaoting@ creaf.uab.es)
}

Received: 29 April 2014 - Published in Biogeosciences Discuss.: 3 June 2014

Revised: 9 September 2014 - Accepted: 26 September 2014 - Published: 13 November 2014

\begin{abstract}
Soil respiration (SR) is a major component of ecosystems' carbon cycles and represents the second largest $\mathrm{CO}_{2}$ flux in the terrestrial biosphere. Soil temperature is considered to be the primary abiotic control on SR, whereas soil moisture is the secondary control factor. However, soil moisture can become the dominant control on SR in very wet or dry conditions. Determining the trigger that makes soil moisture as the primary control factor of SR will provide a deeper understanding on how SR changes under the projected future increase in droughts. Specific objectives of this study were (1) to investigate the seasonal variations and the relationship between SR and both soil temperature and moisture in a Mediterranean riparian forest along a groundwater level gradient; (2) to determine soil moisture thresholds at which SR is controlled by soil moisture rather than by temperature; (3) to compare SR responses under different tree species present in a Mediterranean riparian forest (Alnus glutinosa, Populus nigra and Fraxinus excelsior). Results showed that the heterotrophic soil respiration rate, groundwater level and $30 \mathrm{~cm}$ integral soil moisture $\left(\mathrm{SM}_{30}\right)$ decreased significantly from the riverside moving uphill and showed a pronounced seasonality. SR rates showed significant differences between tree species, with higher SR for P. nigra and lower SR for A. glutinosa. The lower threshold of soil moisture was 20 and $17 \%$ for heterotrophic and total SR, respectively. Daily mean SR rate was positively correlated with soil temperature when soil moisture exceeded the threshold, with $Q_{10}$ values ranging from 1.19 to 2.14; nevertheless, SR became decoupled from soil temperature when soil moisture dropped below these thresholds.
\end{abstract}

\section{Introduction}

Soil is the largest pool of terrestrial organic carbon in the biosphere, storing around $2344 \mathrm{Pg} \mathrm{C}$ in the top $3 \mathrm{~m}$ (Jobbágy and Jackson, 2000). Soil respiration (SR) is the main source of carbon efflux from ecosystems to the atmosphere, accounting for $60-90 \%$ of the total ecosystem respiration (Schimel et al., 2001; Raich et al., 2002). Thus, SR plays an important role in the global carbon balance (Schimel et al., 2001; Raich et al., 2002), and even small changes of SR may induce positive feedbacks to climate change (Schlesinger and Andrews, 2000). Therefore, information of how SR interacts with environmental conditions, such as the response of specific components of soil respiration to temperature and moisture changes, will be a key part of the improvement of process-based models.

On large scales, such as in ecosystems and biomes, net primary production (NPP) may be the most important factor controlling SR (Wardle, 2002). NPP provides the inputs to the soil from aboveground litter and also belowground organic detritus (Raich and Potter, 1995). Moreover, root respiration is strongly dependent on the translocation of photosynthates from the aboveground part of the plant (CurielYuste et al., 2004). At the smaller scale, SR has been found to be very sensitive to soil temperature and soil moisture (Fang and Moncrieff, 2001). Soil temperature has been recognized as the most important environmental factor controlling SR because it affects the respiratory enzymes of both roots and soil microbial biomass (Xu et al., 2011). In general, SR increases exponentially with increases of soil temperature (Epron et al., 1999; Lloyd and Taylor, 1994; Mielnick and Dugas, 2000). In contrast to the positive relationship 
between SR and soil temperature, both very high and very low soil moisture have been shown to diminish the temperature response of SR (Londo et al., 1999; Welsch and Hornberger, 2004) due to the potential oxygen limitations under high soil moisture (Skopp et al., 1990) and due to metabolic drought stress under very low soil moisture (Orchard and Cook, 1983). Soil moisture also affects plant composition and productivity (Häring et al., 2013) and thus controls the quantity and quality of both soil organic matter (SOM) and root exudate supply (Rustad et al., 2000).

Numerous studies have reported the effects of temperature and moisture on SR. However, studies about the combined effects of both factors are relatively few, and the information of how soil moisture affects the relationship between soil temperature and SR is scarce (Bowden et al., 1998; Davidson et al., 2006; Curiel-Yuste et al., 2007). In Mediterranean and semiarid ecosystems, SR is highly sensitive to soil moisture, and the temperature-driven increases in SR are likely dampened by low soil moisture (Conant et al., 2004; Raich and Potter, 1995; Rey et al., 2002). It is still unclear under which circumstances or environmental conditions would the primary control factor of SR switch from temperature to soil moisture.

SR can be divided into autotrophic and heterotrophic respiration by different biological sources (Hanson et al., 2000). Autotrophic respiration, also known as root respiration, is mainly dependent on NPP and tree physiology such as photosynthesis substrate supply (Heinemeyer et al., 2007; Hogberg et al., 2001). Heterotrophic respiration is the sum of microbial decomposition of SOM (Fang et al., 2005; Knorr et al., 2005). In theory, due to the different origins of autotrophic and heterotrophic respiration, they may have different sensitivities toward environmental factors and respond differently to seasonality (Epron et al., 2001; Kuzyakov and Larionova, 2006; Yan et al., 2010).

Riparian areas are characterized with high soil moisture and sustained water table. (McGlynn and Seibert, 2003). In these ecosystems, tree species composition and tree growth are strongly influenced by the topographic position concomitant with the changes in the soil water content. Thus, this may indirectly affect SR through litter input and nutrient availability. Because of the retardation of microbial decomposition with the frequent saturation of soil water, riparian areas tend to accumulate more SOM than hillslope areas do (Sjögersten et al., 2006).

The main objectives of this study were (1) to investigate the seasonal variations and relationships between SR and both soil temperature and moisture in a Mediterranean riparian forest along a groundwater level gradient; (2) to determine soil moisture thresholds at which SR is controlled by soil moisture rather than by temperature, even in such nonwater-stressed environments; (3) to compare SR responses under different tree species present in a Mediterranean riparian forest (Alnus glutinosa, Populus nigra and Fraxinus excelsior). With these aims, we carried out measurements of
SR under different tree species along a groundwater level gradient in a riparian forest in NE Spain. The results of our study may help to better the understanding of the interactions between different components of SR with soil temperature and moisture as well as the role of different tree species. It also provides relevant information for SR model parameterization.

\section{Material and methods}

\subsection{Site description}

The experiment was conducted in a riparian forest growing along the Font de Regàs stream, a headwater tributary of the Tordera River, in Montseny Natural Park (north of Barcelona; $41^{\circ} 50^{\prime} \mathrm{N}, 2^{\circ} 30^{\prime} \mathrm{E}$, altitudinal range 300-1200 ma.s.l.). The forest community of our study site consists of black alder (Alnus glutinosa L.), black locust (Robinia pseudoacacia L.), common ash (Fraxinus excelsior L.) and black poplar (Populus nigra L.). As result of water and nutrient availability, A. glutinosa and P. nigra trees are mostly distributed near the river, whereas $F$. excelsior trees are located further away on the upper site, near the hill. $R$. pseudoacacia trees are scattered over the study area and were not monitored. Mean annual temperature is $12^{\circ} \mathrm{C}$ with maximum and minimum average temperatures of 14 and $10^{\circ} \mathrm{C}$, respectively. The mean annual precipitation is $872 \mathrm{~mm}(1951-2010)$. The riparian soil is sandy loam with low rock content $(<13 \%)$, weakly acidic $(\mathrm{pH}$ of 6.7$)$ and has an average bulk density of $1.09 \mathrm{~g} \mathrm{~cm}^{-3}$.

\subsection{Experimental design}

We divided the groundwater gradient (riparian-hillslope transect) into four levels according to the distance from the riverside and by tree species composition (Fig. 1). The distances of level 1 to level 4 (L1 to L4) from the river centre were $2.7,4.4,6.8$ and $11.8 \mathrm{~m}$, respectively. The three target tree species, $A$. glutinosa, $P$. nigra and $F$. excelsior were located at levels L1, L2 and L3, respectively. To examine the interaction effects on SR of tree species, soil moisture and temperature, we set three riparian-hillslope transects to measure the variation of total SR (sum of soil autotrophic and heterotrophic respiration, hereafter referred to collectively as total $\mathrm{SR}, \mathrm{SR}_{\mathrm{tot}}$ ) from different tree species. Soil chambers were placed $1.5 \mathrm{~m}$ from the stem of the target tree species. Moreover, we also set two transects to measure the topographic effects on soil heterotrophic respiration $\left(\mathrm{SR}_{\mathrm{H}}\right)$. Due to the difficulty of trenching next to the riverbank, chambers for $\mathrm{SR}_{\mathrm{H}}$ were set only at levels L2, L3 and L4. To separate root respiration from $\mathrm{SR}_{\mathrm{H}}$, we inserted a PVC tube (diameter: $65 \mathrm{~cm}$; height: $40 \mathrm{~cm}$ ) into the soil 5 months before starting the measurements. To avoid constraints on groundwater table fluctuations by the PVC tube, we cut two opposite windows 


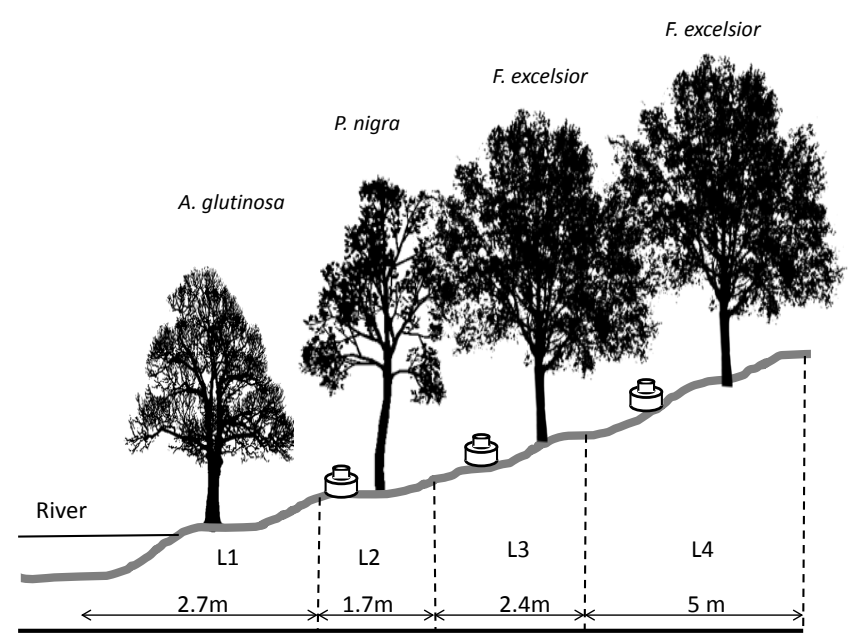

Figure 1. Sketch of levels along a gradient of soil water availability with tree species distribution and $\mathrm{SR}_{\mathrm{H}}$ chamber positions.

into the PVC tube and covered by $65 \mu \mathrm{m}$ mesh to prevent root growth through the windows.

Stainless steel rings were inserted permanently into the soil, down to $3 \mathrm{~cm}$ depth as the base of the soil chambers, and kept free from seedlings throughout the experiment duration. The distances of each soil chamber from the riverside varied slightly due to the tree distribution.

\subsection{Field measurement}

SR and soil temperatures were measured seasonally from summer 2011 to autumn 2012. These measurements were conducted continuously for 1 week within each season. A heavy rainfall event took place in winter 2012, resulting in elevated water levels of the river that washed away most of the litter layer within $3 \mathrm{~m}$ from the river bank.

$\mathrm{CO}_{2}$ concentration was measured in situ with an automatic changeover open system. The system consists of an infrared gas analyser (IRGA, LiCor 6262, LiCor, Inc., Lincoln, NE, USA), a data logger (CR10, Campbell Scientific Inc., UT, USA), 12 pairs of channels, 12 soil chambers, 12 pairs of rotameters, 6 pumps and 2 flowmeters. Each pair of channels consists of two tubes connected to a soil chamber, one attached on the top of chamber (reference $\mathrm{CO}_{2}$ concentration) and another attached at the base for calculating the increment of $\mathrm{CO}_{2}$ concentration provided by SR. Soil chambers were placed at the beginning of each field campaign, and $\mathrm{CO}_{2}$ concentrations were analysed and recorded sequentially over $1 \mathrm{~min}$ intervals at each chamber. Air was continuously forced through all chambers by pumps. Only one chamber was connected at a time to the IRGA to analyse the $\mathrm{CO}_{2}$ concentration of the respective chamber, while air from the others was exhausted to the atmosphere until their own turn. The sequence was programmed every 4 cycles of differential IRGA measurements from 12 chambers, and an additional cycle of absolute IRGA measurement, which was then used to calculate the actual absolute ambient air concentration of $\mathrm{CO}_{2}$ in ppm. The $\mathrm{CO}_{2}$ concentration of the ambient air was determined as the difference between the scrubbed sample, which flows through soda lime and $\mathrm{Mg}\left(\mathrm{ClO}_{4}\right)_{2}$, and the ambient air sample.

Soil chambers were protected by placing a $50 \mathrm{~cm} \times 50 \mathrm{~cm}$ green fine mesh on top to avoid possible heating by direct sunlight during the measurements. Soil temperature of $5 \mathrm{~cm}$ depth was continuously measured with Pt100 temperature sensors and recorded in parallel with the $\mathrm{CO}_{2}$ concentration analysis. Thirty centimetre integral soil moisture $\left(\mathrm{cm}^{3} \mathrm{~cm}^{-3}\right.$, $\mathrm{SM}_{30}$ ) in each level were determined and recorded halfhourly with a moisture reflectometer (CS616, Campbell Scientific). Additionally, we also measured $5 \mathrm{~cm}$ integral soil moisture $\left(\mathrm{SM}_{5}\right)$ next to each soil chamber once per day during each measuring field campaign with impedance probes (ThetaProbe soil moisture sensor, MI2x, Delta-T Devices, Cambridge, UK). A grid of 28 wells (PVC tubes of $35 \mathrm{~mm}$ in diameter) was installed to monitor groundwater table oscillation. Wells were distributed along the study site and at different distances from the stream: 2.7, 4.4, 6.8, $11.8 \mathrm{~m}(n=7)$. Groundwater levels were monitored manually every 2 weeks using a sounding device with acoustic and light signal (Eijkelkamp Agrisearch Equipment). In autumn of 2012, after concluding the measurements, litter layer and soil samples $(15 \mathrm{~cm}$ depth) inside each chamber were collected. Litter layer samples were weighted after oven drying at $65-70^{\circ} \mathrm{C}$ for $24 \mathrm{~h}$. Soil samples were first oven dried at $105^{\circ} \mathrm{C}$ and then analysed to determine their organic carbon and nitrogen content by using the Walkley-Black and Kjeldahl methods, respectively.

\subsection{Statistical analysis}

Statistical analyses were performed with PASW statistics 18 (SPSS Inc., 2009, Chicago, IL, USA). The missing data of soil temperatures were estimated from air temperature values based on a regression analyses between air and soil temperatures. SR, soil temperature and soil moisture data were analysed using ANOVA to examine whether seasonal SR rates were different between levels and tree species. Data used to test the significance in ANOVA were based on daily means. Least significant difference (LSD) was used to detect differences between levels and tree species for each season. We used regression analysis to examine the relationship between SR and soil temperature. An univariate exponential equation was fitted (van 't Hoff, 1898):

$\mathrm{SR}=a e^{b T}$,

where SR is soil respiration rate $\left(\mu \mathrm{molC} \mathrm{m}^{-2} \mathrm{~s}^{-1}\right), T$ is soil temperature $\left({ }^{\circ} \mathrm{C}\right), a$ and $b$ are fitted parameters.

The apparent $Q_{10}$ was calculated as

$Q_{10}=e^{10 b}$ 
Table 1. Soil carbon and nitrogen content and dry weight of litter L and $\mathrm{F}$ organic horizons from soil respiration chambers.

\begin{tabular}{lllll}
\hline Groundwater level & $\mathrm{C} / \mathrm{N}$ & SOC \% & Nitrogen\% & $\begin{array}{l}\text { Litter Layer } \\
\left(\mathrm{kg} \mathrm{m}^{-2}\right)\end{array}$ \\
\hline L2 - Near river & 10.40 & 2.73 & 0.16 & 0.97 \\
L3 - Intermediate & 10.00 & 4.38 & 0.26 & 1.20 \\
L4 - Uphill & 9.15 & 3.36 & 0.23 & 1.67 \\
L1 - A. glutinosa & 12.13 & 2.29 & 0.11 & 0.69 \\
L2 - P. nigra & 10.27 & 3.52 & 0.20 & 1.18 \\
L3 - F. excelsior & 9.67 & 4.85 & 0.30 & 2.21 \\
\hline
\end{tabular}

A $Q_{10}$ value for the whole measurement period was computed for each topographic position and tree species on the basis of daily average SR rate and soil temperature. In addition, we estimated specific $Q_{10}$ values for summer of 2011 and 2012. Data collected were fitted to the exponential equation. In order to understand the interaction between soil temperature and soil moisture and the effect of soil moisture on regulating SR, we applied recursive partitioning analysis to search for the threshold of soil moisture. As models based on partitioning can only handle linear models, the Eq (1) was transformed by linearizing with logarithms:

$\ln \mathrm{SR}=\ln a+b T$

Logarithmic transformed SR values were used as the dependent variable. Once the soil moisture thresholds were obtained, linear and nonlinear regression analyses were used to determine the relationship between SR, soil temperature and soil moisture at each soil moisture interval. The recursive partitioning analysis was conducted in the $R$ statistical environmental using the party package (Zeileis et al., 2008).

\section{Results}

\subsection{Seasonal variation of groundwater level, soil moisture, soil nitrogen and carbon content}

Seasonal variation of air temperature and precipitation was remarkable. The precipitation in 2011 was significantly higher than in 2012, especially in summer. Summer precipitation in 2011 was 4 times higher $(183 \mathrm{~mm})$ than in 2012 (39 mm). SM 30 was significantly higher at L1 (Fig. 2). In summer 2012, due to a remarkable drought, $\mathrm{SM}_{30}$ at $\mathrm{L} 1$ only showed a small decrease with respect to summer 2011; while at the other levels (L2, L3 and L4) $\mathrm{SM}_{30}$ was markedly decreased. Groundwater levels showed no seasonal variation but were significantly different between them.

Soil near the river contained less organic carbon and nitrogen, but a higher $\mathrm{C}: \mathrm{N}$ ratio, with a $\mathrm{C}: \mathrm{N}$ ratio of 12.13 (Table 1). Soil $\mathrm{C}: \mathrm{N}$ ratio decreased from the riverside going uphill, whereas the dry weight of litter layer increased from the riverside going uphill. The largest amount of dry weight of litter layer was found under F. excelsior, and coincided

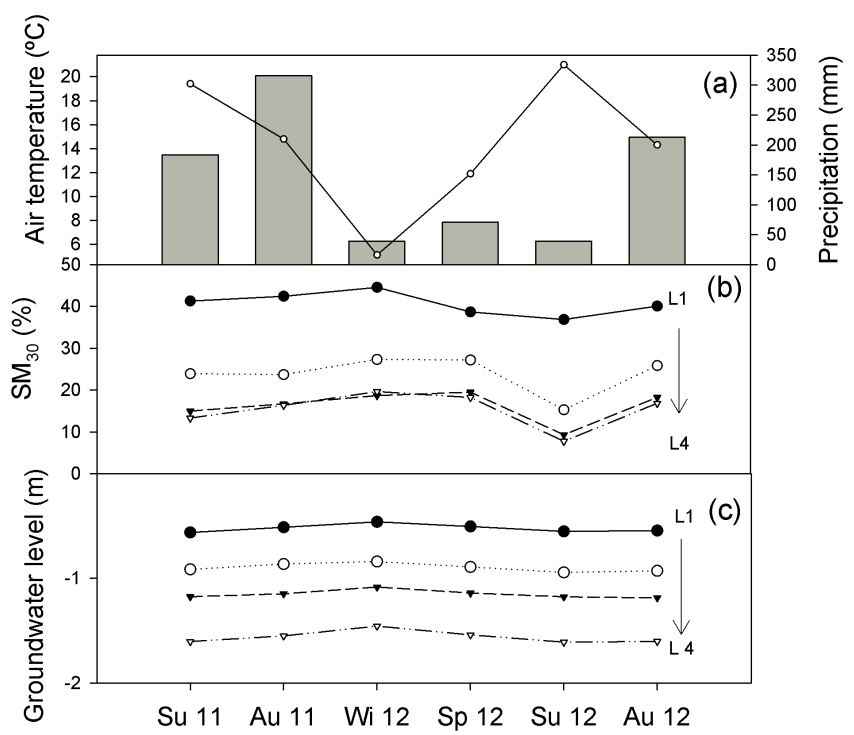

Figure 2. Seasonal changes of summer 2011 (Su 11), autumn 2011 (Au 11), winter 2012 (Wi 12), spring 2012 (Sp 12) summer 2012 (Su 12) and autumn 2012 (Au12) in (a) mean seasonal air temperature and precipitation; (b) $30 \mathrm{~cm}$ integral soil moisture $\left(\mathrm{SM}_{30}\right)$; (c) groundwater level, value represents the depth of groundwater level from soil surface (L1, L2, L3 and L4).

with the highest soil organic carbon (SOC) and soil nitrogen concentrations between all levels.

\subsection{Seasonal variation of $\mathrm{SR}_{\mathrm{H}}$ along hillslope transect}

$\mathrm{SR}_{\mathrm{H}}$ rates ranged from $0.17 \mu \mathrm{molCm} \mathrm{Cm}^{-2} \mathrm{~s}^{-1}$ (in winter, L4) to $1.69 \mu \mathrm{mol} \mathrm{Cm}^{-2} \mathrm{~s}^{-1}$ (in summer, L2, Fig. 3a-d). $\mathrm{SR}_{\mathrm{H}}$ decreased significantly from riparian zone (L2) to hill zone (L4), especially in summer. $\mathrm{SR}_{\mathrm{H}}$ measured from different levels were significantly different in all seasons $(P<0.05)$. $\mathrm{SR}_{\mathrm{H}}$ at L2 had a higher variability during the whole experiment. Minimum soil temperature coincided with maximum $\mathrm{SM}_{5}$ in winter while maximum soil temperature was recorded in summer when $\mathrm{SM}_{5}$ was lowest. $\mathrm{SR}_{\mathrm{H}}$ varied markedly during the year following the change of soil temperature from summer 2011 to spring 2012, and the changes of $\mathrm{SM}_{5}$ for summer and autumn 2012. As expected, $\mathrm{SR}_{\mathrm{H}}$ was lower during winter when soil temperatures were the lowest of the year, and $\mathrm{SR}_{\mathrm{H}}$ was higher during the growing season.

\subsection{Tree species and topographic effects on $\mathbf{S R}_{\text {tot }}$ and $\mathrm{SM}_{30}$}

The observed variation of $\mathrm{SR}_{\mathrm{tot}}$ for the three tree species followed the change of soil temperature over the year (Fig. 3e-h). $\mathrm{SR}_{\mathrm{tot}}$ of P. nigra was the highest one, especially during summer, and $\mathrm{SR}_{\text {tot }}$ of $A$. glutinosa was the lowest one throughout the year. There were no significant differences of soil temperatures between tree species locations. $\mathrm{SM}_{5} \mathrm{did}$ not differ between tree species locations but there was a tendency 
Table 2. Comparison of soil respiration rates (SR), soil moisture (SM) and $Q_{10}$ values in 2011 and 2012 summer campaigns. Heterotrophic $\mathrm{SR}\left(\mathrm{SR}_{\mathrm{H}}\right)$. Total $\mathrm{SR}\left(\mathrm{SR}_{\mathrm{tot}}\right)$. Five centimetre integral soil moisture $\left(\mathrm{SM}_{5}\right)$. Thirty centimetre integral soil moisture $\left(\mathrm{SM}_{30}\right)$.

\begin{tabular}{lllllllllllll}
\hline & & \multicolumn{3}{c}{$\mathrm{SR}\left(\mu \mathrm{molC} \mathrm{Cm}^{-2} \mathrm{~s}^{-1}\right)$} & \multicolumn{3}{c}{$\mathrm{SM}_{5}(\%)$} & \multicolumn{3}{c}{$\mathrm{SM}_{30}(\%)$} & \multicolumn{2}{c}{$Q_{10}$} \\
& Chamber & 2011 & 2012 & Reduction & 2011 & 2012 & Reduction & 2011 & 2012 & Reduction & 2011 & 2012 \\
\hline $\mathrm{SR}_{\mathrm{H}}$ & L2 - Near river & 1.65 & 0.84 & $49 \%$ & 27.10 & 14.94 & $45 \%$ & 22.22 & 14.51 & $35 \%$ & 1.09 & 0.76 \\
& L3 - Intermediate & 0.98 & 0.70 & $28 \%$ & 31.68 & 14.91 & $53 \%$ & 12.60 & 9.22 & $27 \%$ & 1.04 & 0.88 \\
& L4- Uphill & 0.74 & 0.50 & $32 \%$ & 38.02 & 14.19 & $63 \%$ & 10.87 & 8.13 & $25 \%$ & 0.97 & 0.84 \\
$\mathrm{SR}_{\text {tot }}$ & L1 - A. glutinosa & 1.24 & 0.78 & $37 \%$ & 27.24 & 13.04 & $52 \%$ & 42.49 & 36.58 & $14 \%$ & 1.31 & 0.80 \\
& L2 - P. nigra & 1.42 & 1.13 & $21 \%$ & 26.22 & 12.93 & $51 \%$ & 22.22 & 14.51 & $35 \%$ & 1.17 & 0.63 \\
& L3-F. excelsior & 1.26 & 0.76 & $40 \%$ & 26.45 & 12.87 & $51 \%$ & 12.60 & 9.22 & $27 \%$ & 1.40 & 1.14 \\
\hline
\end{tabular}

All data of SR, $\mathrm{SM}_{5}$ and $\mathrm{SM}_{30}$ were significantly different between 2011 and 2012. All $P$ values $<0.001$.

Table 3. Comparison of soil respiration rates (SR) and soil moisture (SM) after a rainfall event of 13.5 mm in summer 2012. Heterotrophic SR $\left(\mathrm{SR}_{\mathrm{H}}\right)$. Total $\mathrm{SR}\left(\mathrm{SR}_{\mathrm{tot}}\right)$. Five centimetre integral soil moisture $\left(\mathrm{SM}_{5}\right)$. Thirty centimetre integral soil moisture $\left(\mathrm{SM}_{30}\right)$. Data were averaged for the 2 days before and 2 days after the rainfall event.

\begin{tabular}{lllllllllll}
\hline & & \multicolumn{3}{c}{$\mathrm{SR}\left(\mu \mathrm{mol} \mathrm{Cm} \mathrm{s}^{-1}\right)$} & \multicolumn{2}{c}{$\mathrm{SM}_{5}(\%)$} & \multicolumn{3}{c}{$\mathrm{SM}_{30}(\%)$} \\
& Chamber & before & after & increase & before & after & increase & before & after & increase \\
\hline $\mathrm{SR}_{\mathrm{H}}$ & L2 - Near river & 0.66 & 1.00 & $52 \%$ & 14.09 & 18.84 & $34 \%$ & 14.45 & 14.50 & $0 \%$ \\
& L3 - Intermediate & 0.59 & 0.80 & $34 \%$ & 15.19 & 18.37 & $21 \%$ & 8.46 & 10.15 & $20 \%$ \\
& L4 - Uphill & 0.41 & 0.59 & $45 \%$ & 12.06 & 17.51 & $45 \%$ & 6.97 & 9.64 & $38 \%$ \\
$\mathrm{SR}_{\text {tot }}$ & L1 - A. glutinosa & 0.67 & 1.04 & $54 \%$ & 11.27 & 16.91 & $50 \%$ & 36.13 & 37.48 & $4 \%$ \\
& L2 - P. nigra & 0.99 & 1.66 & $68 \%$ & 10.86 & 18.86 & $74 \%$ & 14.45 & 14.50 & $0 \%$ \\
& L3 - F. excelsior & 0.68 & 0.98 & $44 \%$ & 11.10 & 17.20 & $55 \%$ & 8.46 & 10.15 & $20 \%$ \\
\hline
\end{tabular}

towards a higher $\mathrm{SM}_{5}$ under $F$. excelsior. $\mathrm{SM}_{30}$ was significantly different between levels for all seasons. The variation of $\mathrm{SM}_{30}$ at $\mathrm{L} 1$ was lower and showed less seasonal variability, maintaining most of the $\mathrm{SM}_{30}$ values around $40 \%$. During both summers 2011 and 2012, $\mathrm{SM}_{30}$ at L3 dropped to around $10 \%$, which is even lower than the $\mathrm{SM}_{5}$ at $\mathrm{L} 4$ where F. excelsior is found.

\subsection{Drought and rain pulse effects on SR}

The low precipitation of summer 2012 caused a significant reduction of around $50 \%$ of SM5, $14-35 \%$ of SM30 and at the same time a reduction of SR between 21 and $49 \%$. The $Q_{10}$ values ranged from $0.97-1.40$ in summer 2011 and $0.63-1.14$ in summer 2012 (Table 2).

A rainfall event $(13.5 \mathrm{~mm})$ during the measurement period of summer 2012 caused a significant increase of soil moisture and SR rates at all levels (L1 to L4). The $\mathrm{SM}_{5}$ increased around $21-74 \%$ after the rainfall event even though it only caused a $0-38 \%$ increase of the $\mathrm{SM}_{30}$ (Table 3). This rainfall event caused a sharp increase of SR from $0.41-0.99 \mu \mathrm{mol} \mathrm{C} \mathrm{m}^{-2} \mathrm{~s}^{-1}$ to $0.59-1.66 \mu \mathrm{mol} \mathrm{C} \mathrm{m}^{-2} \mathrm{~s}^{-1}$, which corresponds to an increase of SR around 34 to $68 \%$.

\subsection{The switch of primary control factor of SR}

We identified three $\mathrm{SM}_{5}$ intervals for each $\mathrm{SR}_{\mathrm{H}}$ and $\mathrm{SR}_{\text {tot }}$ (Table 4), which suggests the existence of thresholds in soil moisture effects. SR was positively related $(P<0.001)$ to soil temperature when $\mathrm{SM}_{5}$ was higher than $23 \%$ for $\mathrm{SR}_{\mathrm{H}}$ or higher than $27 \%$ for $\mathrm{SR}_{\text {tot }}$. The lower thresholds for $\mathrm{SR}_{\mathrm{H}}$ and $\mathrm{SR}_{\text {tot }}$ were 20 and $17 \%$ of $\mathrm{SM}_{5}$ respectively. Under the lower bound value, $\mathrm{SR}_{\mathrm{H}}$ showed a significantly positive relationship with $\mathrm{SM}_{5}$ (Fig. 4, linear regression with $r^{2}$ of 0.89 , 0.92 and 0.91 for L2, L3 and L4) while SR $_{\text {tot }}$ showed a weak positive relationship with $\mathrm{SM}_{5}$ (Fig. 5, linear regression with $r^{2}$ of $0.56,0.11$ and 0.10 for L1, L2 and L3). The exponential model based on soil temperature accounts for 68 to $84 \%$ of the variation in both $\mathrm{SR}_{\mathrm{H}}$ and $\mathrm{SR}_{\text {tot }}$ rates at the higher $\mathrm{SM}_{5}$ interval values. The fitted $Q_{10}$ values in high $\mathrm{SM}_{5}$ intervals ranged from 1.49 to 2.14 . Generally the $Q_{10}$ values of $\mathrm{SR}_{\mathrm{H}}$ were lower than the $Q_{10}$ of $\mathrm{SR}_{\text {tot }}$. 
Table 4. Exponential relationships between soil respiration (SR) and soil temperature $(T)$, and $Q_{10}$ for different $\mathrm{SM}_{5}$ intervals. Heterotrophic $\mathrm{SR}\left(\mathrm{SR}_{\mathrm{H}}\right)$. Total $\mathrm{SR}\left(\mathrm{SR}_{\mathrm{tot}}\right) .\left(\mathrm{SM}_{5}\right)$ is $5 \mathrm{~cm}$ integral soil moisture.

\begin{tabular}{|c|c|c|c|c|c|c|c|c|c|c|}
\hline & & \multicolumn{3}{|c|}{$\mathrm{SM}_{5}>23 \%$} & \multicolumn{3}{|c|}{$23 \%>\mathrm{SM}_{5}>20 \%$} & \multicolumn{3}{|c|}{$\mathrm{SM}_{5}<20 \%$} \\
\hline & & Fn & $R^{2}$ & $Q_{10}$ & Fn & $R^{2}$ & $Q_{10}$ & Fn & $R^{2}$ & $Q_{10}$ \\
\hline \multirow[t]{3}{*}{$\mathrm{SR}_{\mathrm{H}}$} & L2 - Near river & $\mathrm{SR}_{\mathrm{H}}=0.52 e^{0.05 T}$ & $0.77^{* * *}$ & 1.58 & $\mathrm{SR}_{\mathrm{H}}=0.68 e^{0.02 T}$ & $0.74^{*}$ & 1.25 & $\mathrm{SR}_{\mathrm{H}}=2.10 e^{0.4 T}$ & $0.58^{* *}$ & 0.02 \\
\hline & L4 - Uphill & $\mathrm{SR}_{\mathrm{H}}=0.40 e^{0.05 T}$ & $0.84^{* * *}$ & 1.58 & $\mathrm{SR}_{\mathrm{H}}=0.64 e^{0.02 T}$ & $0.66^{*}$ & 1.19 & $\mathrm{SR}_{\mathrm{H}}=1.34 e^{-0.03 T}$ & $0.34^{*}$ & 0.76 \\
\hline & & \multicolumn{3}{|c|}{$\mathrm{SM}_{5}>27 \%$} & \multicolumn{3}{|c|}{$27 \%>\mathrm{SM}_{5}>17 \%$} & \multicolumn{3}{|c|}{$\mathrm{SM}_{5}<17 \%$} \\
\hline \multirow[t]{2}{*}{$\mathrm{SR}_{\text {tot }}$} & L1 - A. glutinosa & $\mathrm{SR}_{\mathrm{tot}}=0.53 e^{0.04 T}$ & $0.77^{* * *}$ & 1.54 & $\mathrm{SR}_{\mathrm{tot}}=0.69 e^{0.03 T}$ & $0.83^{* * *}$ & 1.30 & $\mathrm{SR}_{\mathrm{tot}}=0.77 e^{0.01 T}$ & 0.01 & 1.06 \\
\hline & L3 - F. excelsior & $\mathrm{SR}_{\mathrm{tot}}=0.32 e^{0.08 T}$ & $0.68^{* * *}$ & 2.14 & $\mathrm{SR}_{\mathrm{tot}}=0.56 e^{0.03 T}$ & $0.62^{* * *}$ & 1.40 & $\mathrm{SR}_{\mathrm{tot}}=1.30 e^{-0.02 T}$ & $0.25^{* *}$ & 0.82 \\
\hline
\end{tabular}

${ }^{*} P<0.05 ;{ }^{* *} P<0.01 ;{ }^{* * *} P<0.001$

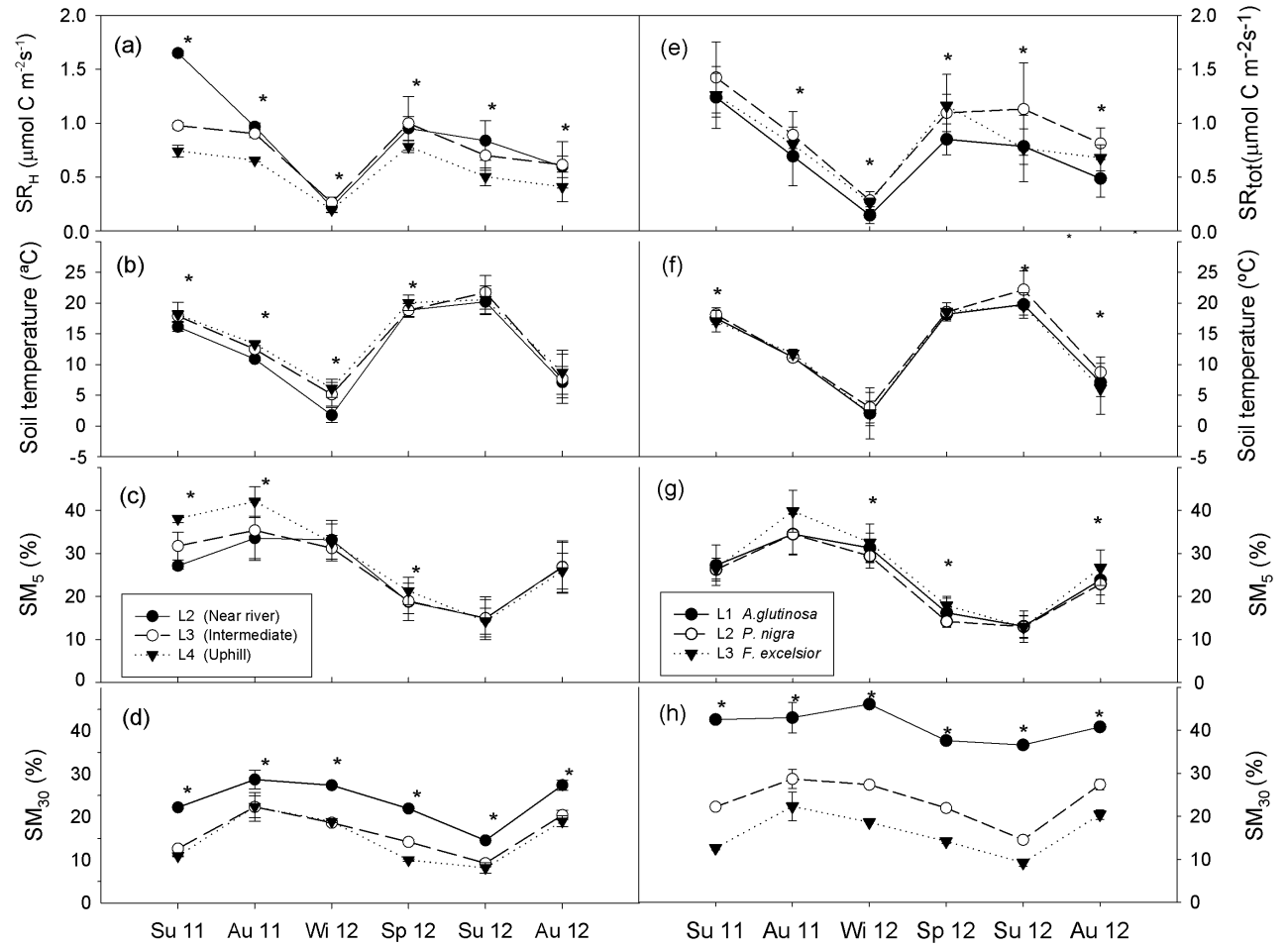

Figure 3. Seasonal variation of soil respiration, soil temperature and soil moisture. (a-d) Data of soil heterotrophic respiration: (a) SRH along groundwater level gradient. (b) $5 \mathrm{~cm}$ soil temperature. (c) $5 \mathrm{~cm}$ integral soil moisture $\left(\mathrm{SM}_{5}\right)$. (d) $30 \mathrm{~cm}$ integral soil moisture ( $\left.\mathrm{SM}_{30}\right)$. (e-h) Data of total soil respiration rates (SRtot) of three tree species. (e) SR tot under different tree species. (f) $5 \mathrm{~cm}$ soil temperature. (g) $5 \mathrm{~cm}$ integral soil moisture $\left(\mathrm{SM}_{5}\right)$. (h) $30 \mathrm{~cm}$ integral soil moisture $\left(\mathrm{SM}_{30}\right)$. All values are mean $\mathrm{SD}$. Data points marked with indicate significant differences between species at $P<0.05$ (For details, please see to Appendices A and B).

\section{Discussion}

\subsection{Effect of groundwater level and soil moisture on SR}

In the studies of Martin and Bolstad (2005) and Pacific et al. (2008), it was indicated that the amount and availability of soil water varies depending on landscape position and topography. Both studies also show that small differences in micro-topography appear to be important in driving soil moisture conditions. This is in accordance with our results; the overall seasonal trends of soil moisture were similar, but differences in the relative magnitude of soil moisture still can be found between different levels.

In our study site, the $\mathrm{SR}_{\mathrm{H}}$ was significantly higher at $\mathrm{L} 2$ and decreased with the distance from the river. At the same time, $\mathrm{SR}_{\text {tot }}$ of A. glutinosa at L1 was significantly lower than the other two species found at L2 and L3. This result could be explained by limitations of SR imposed by groundwater 


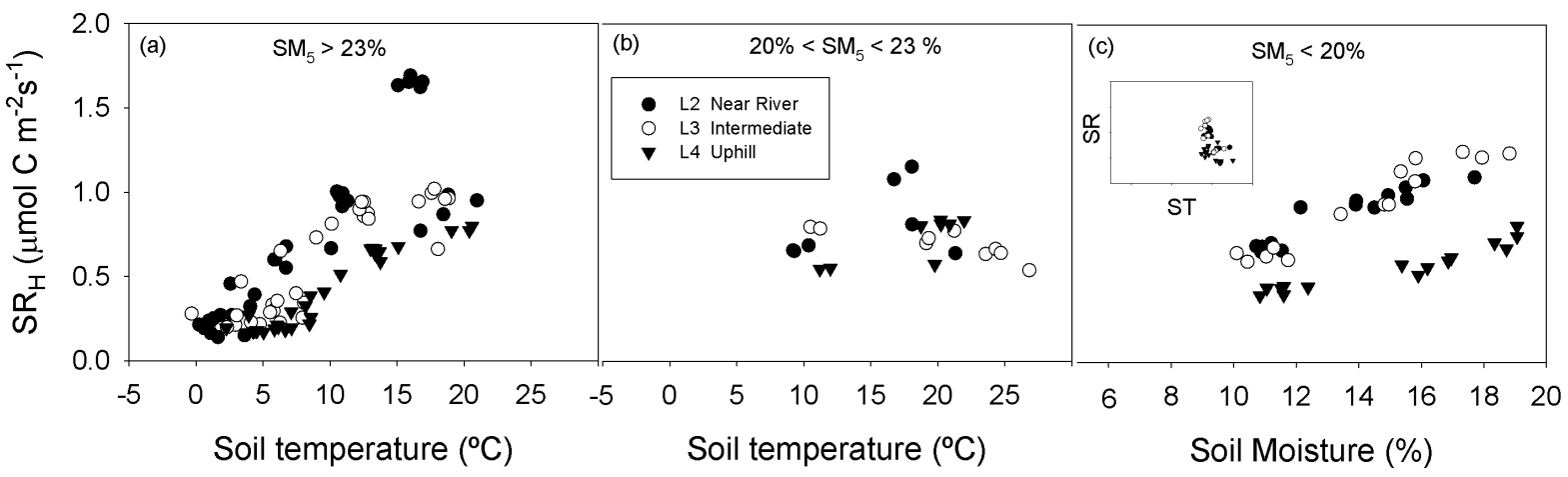

Figure 4. Differentiation of soil temperature (ST) and soil moisture (SM) as primary controlling factors for $\mathrm{SR}_{\mathrm{H}}$. At $\mathrm{SM}_{5} \geq 23 \%$, there are positive correlations of $\mathrm{SR}_{\mathrm{H}}$ with soil temperature in all levels (a). At $20 \% \leq \mathrm{SM}_{5}<23 \%$, there is a transition with no clear relationship of either SM or ST with $\mathrm{SR}_{\mathrm{H}}$ (b). At $\mathrm{SM}_{5}<20 \%$, there is no relationship between SR and ST as the inset figure shows (c); it switches from $\mathrm{ST}$ to $\mathrm{SM}_{5}$ as the controlling factor with positive correlations between $\mathrm{SR}_{\mathrm{H}}$ and $\mathrm{SM}_{5}$ for all levels. Campaigns with $\mathrm{SM}_{5}<20 \%$ were all from spring and summer 2012. $\mathrm{SM}_{5}$ (5 cm integral soil moisture).

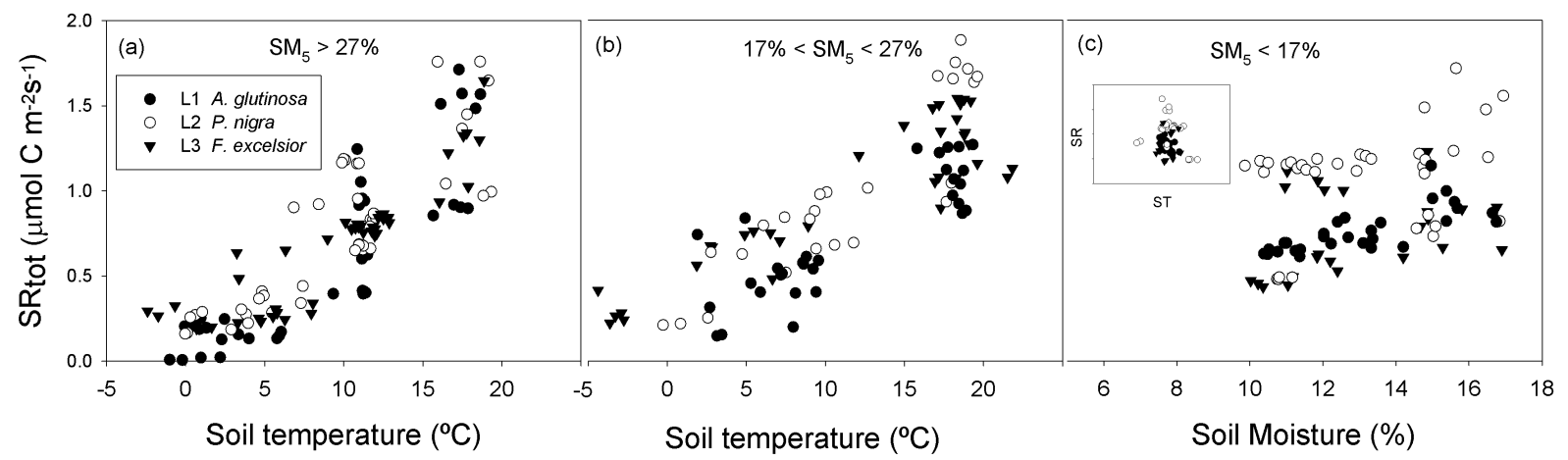

Figure 5. Differentiation of soil temperature (ST) and soil moisture (SM) as primary controlling factors for $\mathrm{SR}_{\text {tot }}$. At $\mathrm{SM}_{5} \geq 27 \%$, there are positive correlations of $\mathrm{SR}_{\text {tot }}$ with soil temperature under all tree species (a). At $17 \% \leq \mathrm{SM}_{5}<27 \%$, there are positive but slightly weaker correlations of $\mathrm{SR}_{\text {tot }}$ with soil temperature under all tree species (b). At $\mathrm{SM}_{5}<17 \%$, there is no relationship between $\mathrm{SR}$ and $\mathrm{ST}$ as the inset figure shows (c); it switches from $\mathrm{ST}_{\text {to }} \mathrm{SM}_{5}$ as the controlling factor with positive correlations between $\mathrm{SR}_{\text {tot }}$ and $\mathrm{SM}_{5}$ for all tree species. Campaigns with $\mathrm{SM}_{5}<17 \%$ were all from spring and summer $2012 . \mathrm{SM}_{5}(5 \mathrm{~cm}$ integral soil moisture).

level in two different ways. First, when the groundwater level is low, the drought stresses soil microbial and root respiration activity; second, when groundwater level is high and close to topsoil surface, it limits soil aeration and likely reduces the effective respiring soil volume. Pacific et al. (2008) showed that the soil $\mathrm{CO}_{2}$ concentrations were significantly higher in the riparian zone as a result of higher soil moisture. In contrast, Zanchi et al. (2011) found lower SR in plots after drainage, and suggested that the low $\mathrm{C}$ and $\mathrm{N}$ content in the topsoil near the river, where most of the soil $\mathrm{CO}_{2}$ respiration is produced, could partially explain that low SR. The discrepancy of these two studies could be associated with the different drainage regimes as the poorly drained plots imply the anaerobic inhibition of SR. In our study, however, $\mathrm{SR}_{\mathrm{H}}$ was measured at L2, L3 and L4 under well-drained conditions, and $\mathrm{SR}_{\mathrm{H}}$ decreased concomitantly with the decrease in the availability of soil water. Nonetheless, $\mathrm{SR}_{\text {tot }}$ of A. glutinosa was measured at $\mathrm{L} 1$, where the soils sometimes experienced flooding or poor draining conditions, and the root respiration may be inhibited by the high groundwater level.

Additionally, landscape position and topography not only altered the availability of soil water but also affected the annual range of soil moisture. This was shown in Zanchi et al. (2011), studying riparian SR in Amazonia. They indicated that riparian soil is very sensitive to the changes of water-flooding regimes. The high groundwater table in riparian zones implies intermittent anaerobic conditions and the inhibition of diffusion during water saturation. These differences in soil moisture caused by site topography may result in differences in SR even though the soil temperatures were similar among all sites. The different behaviours of $\mathrm{SR}_{\mathrm{H}}$ and $\mathrm{SR}_{\text {tot }}$ from L1 to L4 from our results indicate a different contribution of $\mathrm{SR}_{\mathrm{H}}$ to $\mathrm{SR}_{\mathrm{tot}}$. As the root system of A. glutinosa may constantly experience a saturated water regime, the relative contribution from root respiration may be much lower than the one of the other two species. 


\subsection{Rain pulse and drought effects on SR}

The Mediterranean climate is characterized by summer droughts that particularly affect the top soil layers; therefore, rainfall events during these dry periods can trigger abrupt increases in SR that last for days (Bowling et al., 2011; Cisneros-Dozal et al., 2007; Lee et al., 2004; Unger et al., 2010). Lee et al. (2004) simulated precipitation and found that hardwood forest floors were very sensitive to changes in moisture in the upper soil layers. Moreover, Wang et al. (2012) noted that the response of litterfall respiration is very sensitive to rainfall, and the increase in soil moisture by rainfall primarily enhanced the litterfall respiration but decreased mineral SR. Similar results were published by Casals et al. (2011), who reported that SR after a precipitation pulse was mostly derived from $\mathrm{SR}_{\mathrm{H}}$ with a contribution up to $70 \%$ of $\mathrm{SR}_{\text {tot }}$. Hence, our findings seem to be consistent with these previous studies.

\subsection{Confounding effects of temperature and moisture on SR}

This study aimed at assessing the importance of soil moisture on soil respiration and determining the threshold of soil moisture at which soil moisture overrules temperature in controlling SR. The response of SR to soil moisture has been widely studied and described by various types of functions such as linear or logarithmic functions, depending on the soil type, climate or vegetation type (Comstedt et al., 2010; Epron et al., 1999; Orchard and Cook, 1983). In our study, the seasonal courses of $\mathrm{SR}_{\mathrm{H}}$ and $\mathrm{SR}_{\text {tot }}$ generally followed the seasonal cycle of temperature, but were moderated by soil moisture. Such a relationship is in agreement with other previous studies (Davidson et al., 1998; Martin and Bolstad, 2005; Wang et al., 2013).

The positive linear relationship between SR and soil moisture in low soil moisture conditions found in our work agrees with many previous studies where low soil moisture constrains SR (Almagro et al., 2009; Davidson et al., 1998; Keith et al., 1997; Rey et al., 2002; Wang et al., 2013; Xu and Qi, 2001). In our study, the low soil moisture and warmer temperatures actually reduced SR rates, resulting in lower $Q_{10}$ values at the lower soil moisture. A similar decline of $Q_{10}$ with decreasing soil moisture was reported by Conant et al. (2004), Curiel-Yuste et al. (2003) and Wen et al. (2006). Low soil water content not only reduces the contact between the substrate, enzymes and microbes, it also decreases the substrate supply due to the increased drying-out of litter and topsoil layer (Davidson et al., 2006). Another possible reason for the observed lower $Q_{10}$ is that the reduction of photosynthesis decreases the translocation of photosynthates to the rhizosphere (Hogberg et al., 2001; Nordgren et al., 2003).

In a Norway spruce stand, Gärdenäs (2000) found that litter moisture explained most of the variation of SR, whereas mineral soil moisture, air and litter temperature had no ef- fects on SR. Our results showed that the seasonal variations of $\mathrm{SR}_{\mathrm{H}}$ and $\mathrm{SR}_{\text {tot }}$ were mainly controlled by soil temperature, with a secondary influence of soil moisture $\left(\mathrm{SM}_{5}\right)$. Using the recursive partitioning method, we have identified clear thresholds for $\mathrm{SM}_{5}$ effects on the temperature sensitivity of SR. Soil moisture thresholds at which SR temperature sensitivity is reduced have been found in several studies from different ecosystems (Fang and Moncrieff, 2001; GaumontGuay et al., 2006; Jassal et al., 2008; Lellei-Kovács et al., 2011; Palmroth et al., 2005; Wang et al., 2013). However, the threshold values in soil moisture seem to be site specific as the factors limiting water uptake by plants and microbes may differ by ecosystem. Even in the same climate region, different soil moisture thresholds have been found in previous studies. For example, Almagro et al. (2009) investigated how soil moisture modulated the sensitivity of soil respiration in different ecosystems in the Mediterranean region and found that the threshold value of soil moisture was $10 \%$. Above this soil moisture values, $Q_{10}$ ranged from 1.86 to 2.20 and decreased to 0.44 to 0.63 when soil moisture was lower than $10 \%$. However, Rey et al. (2002) found in a Mediterranean oak forest that soil temperature accounted for $85 \%$ of the variation of SR when soil moisture was above $20 \%$ with a $\mathrm{Q}_{10}$ value of 2.34. Furthermore, Xu and Qi (2001) found that with soil moisture higher than $14 \%$, the $Q_{10}$ value was 1.8 and decreased to 1.4 when soil moisture was lower than $14 \%$.

\subsection{Other factors affecting SR}

In addition to soil moisture threshold values, we also found variations of $\mathrm{SR}_{\mathrm{H}}$ and $\mathrm{SR}_{\mathrm{tot}}$ between location and tree species in each soil moisture interval. For example, when $\mathrm{SM}_{5}$ was lower than $20 \%, \mathrm{SR}_{\mathrm{H}}$ measured at L4 was always lower than $\mathrm{SR}_{\mathrm{H}}$ measured at $\mathrm{L} 2$ and $\mathrm{L} 3$. When $\mathrm{SM}_{5}$ was lower than $17 \%, \mathrm{SR}_{\mathrm{tot}}$ of P. nigra was significantly higher than for the other two species, suggesting that there are still other factors affecting $\mathrm{SR}_{\mathrm{H}}$ and $\mathrm{SR}_{\text {tot }}$ variations. Several explanations for this result are plausible. First, spatial variability in vegetation can affect SR due to differences in root respiration and the quantity and quality of detritus (Raich and Tufekcioglu, 2000). These biophysical gradients across landscape positions can lead to strong spatial heterogeneity in SR. Tree species in our study site exhibit different litterfall temporal patterns and may also contribute to the seasonal variation of the availability of SOC and nutrients to the microbial community and roots. Second, the vitality of tree species in responses to soil water regime could generate different root respiration rates. Additional data of daily sap flow of the studied trees from our study site (data not shown) confirmed the differences in tree transpiration and growth activity. For example, the water use efficiency of $P$. nigra was highest, followed by F. excelsior and A. glutinosa. Additionally, the mean diameter at breast height (DBH) of $P$. nigra is larger than mean DBH of the other tree species. P. nigra may be 
more efficient in taking up water and nutrients compared to the other two tree species.

\section{Conclusions}

This research demonstrates how soil moisture constrains the relationship between SR and soil temperature. We present critical threshold values of soil moisture where SR dependency on soil moisture overrules soil temperature dependency. Our results also reveal the importance of soil moisture as a predictor of SR even in a non-water-stressed environment such as riparian forests. Our findings provide support for modelling approaches that include soil temperature and soil moisture by making available parameters to predict SR rates. This study also has implications for a better understanding of global change impacts on the carbon cycle since soil water availability will likely become an increasingly crucial factor for some regions that are expected to suffer more frequent and severe droughts under climate change. 


\section{Appendix A}

Table A1. Analysis of variance (ANOVA) statistics for soil temperature (ST) and soil moisture (SM): $\mathrm{SM}_{5}, \mathrm{SM}_{30}$ and heterotrophic soil respiration $\left(\mathrm{SR}_{\mathrm{H}}\right)$ of different levels of the same season (mean $\left.\pm \mathrm{SD}\right)$. LSD was used to test post hoc. Means with the same letter in parentheses are not significantly different $(P<0.05)$.

\begin{tabular}{|c|c|c|c|c|c|c|}
\hline \multirow{2}{*}{ Campaign } & \multicolumn{3}{|c|}{ ST } & \multicolumn{3}{|c|}{$\mathrm{SM}_{5}$} \\
\hline & L2 & L3 & L4 & L2 & L3 & L4 \\
\hline 2011 Summer & $16.11 \pm 0.73(A)$ & $17.88 \pm 0.88(A B)$ & $18.12 \pm 2.02(B)$ & $27.11 \pm 0.74(A)$ & $31.68 \pm 3.20(B)$ & $38.02 \pm 0.87(C)$ \\
\hline 2011 Autumn & $10.87 \pm 0.30(A)$ & $12.48 \pm 0.24(B)$ & $13.33 \pm 0.25(C)$ & $33.51 \pm 4.75(A)$ & $35.33 \pm 7.00(A)$ & $42.05 \pm 3.40(B)$ \\
\hline 2012 Winter & $1.75 \pm 1.22(A)$ & $5.13 \pm 1.92(B)$ & $6.11 \pm 1.50(B)$ & $33.14 \pm 4.50(A)$ & $31.21 \pm 3.00(A)$ & $32.52 \pm 4.30(A)$ \\
\hline 2012 Spring & $18.82 \pm 1.13(A)$ & $18.81 \pm 1.04(A)$ & $20.03 \pm 1.25(B)$ & $18.73 \pm 4.31(A)$ & $18.87 \pm 2.89(A)$ & $21.26 \pm 3.18(A)$ \\
\hline 2012 Summer & $20.18 \pm 2.05(\mathrm{~A})$ & $21.70 \pm 2.74(\mathrm{~A})$ & $20.80 \pm 2.40(\mathrm{~A})$ & $14.94 \pm 4.99(A)$ & $14.91 \pm 4.35(A)$ & $14.19 \pm 3.04(A)$ \\
\hline \multirow[t]{3}{*}{2012 Autumn } & $7.11 \pm 2.58(\mathrm{~A})$ & $7.66 \pm 3.98(\mathrm{~A})$ & $8.73 \pm 3.38(\mathrm{~A})$ & $26.87 \pm 6.08(A)$ & $26.77 \pm 5.80(A)$ & $25.84 \pm 4.21(A)$ \\
\hline & \multicolumn{3}{|c|}{$\mathrm{SM}_{30}$} & \multicolumn{3}{|c|}{$\mathrm{SR}_{\mathrm{H}}$} \\
\hline & L2 & L3 & L4 & L2 & L3 & L4 \\
\hline 2011 Summer & $22.22 \pm 0.23(A)$ & $12.60 \pm 0.36(B)$ & $10.87 \pm 0.1(C) 0$ & $1.65 \pm 0.03(A)$ & $0.98 \pm 0.03(B)$ & $0.52 \pm 0.32(C)$ \\
\hline 2011 Autumn & $28.69 \pm 2.20(A)$ & $22.31 \pm 3.32(B)$ & $22.37 \pm 2.51(B)$ & $0.97 \pm 0.04(A)$ & $0.90 \pm 0.04(B)$ & $0.66 \pm 0.01(C)$ \\
\hline 2012 Winter & $27.35 \pm 0.22(A)$ & $18.61 \pm 0.18(B)$ & $18.90 \pm 0.24(C)$ & $0.22 \pm 0.66(A B)$ & $0.26 \pm 0.05(A)$ & $0.20 \pm 0.03(B)$ \\
\hline 2012 Spring & $21.91 \pm 0.41(A)$ & $14.17 \pm 0.51(B)$ & $9.96 \pm 0.25(C)$ & $0.95 \pm 0.11(A)$ & $1.00 \pm 0.25(A)$ & $0.78 \pm 0.05(B)$ \\
\hline 2012 Summer & $14.51 \pm 0.07(A)$ & $9.22 \pm 0.78(B)$ & $8.14 \pm 1.25(C)$ & $0.84 \pm 0.18(A)$ & $0.70 \pm 0.14(B)$ & $0.50 \pm 0.08(C)$ \\
\hline 2012 Autumn & $27.27 \pm 1.12(A)$ & $20.38 \pm 1.03(B)$ & $19.01 \pm 1.14(C)$ & $0.59 \pm 0.10(A)$ & $0.61 \pm 0.21(A)$ & $0.41 \pm 0.14(B)$ \\
\hline
\end{tabular}




\section{Appendix B}

Table B1. Analysis of variance (ANOVA) statistics for soil temperature (ST) and soil moisture (SM): $\mathrm{SM}_{5}$, $\mathrm{SM}_{30}$, and total soil respiration $\left(\mathrm{SR}_{\mathrm{tot}}\right)$ of different tree species of the same season. LSD was used to test post hoc. Means with the same letter in parentheses are not significantly different $(P<0.05)$.

\begin{tabular}{|c|c|c|c|c|c|c|}
\hline \multirow[t]{2}{*}{ Campaign } & \multicolumn{3}{|c|}{ ST } & \multicolumn{3}{|c|}{$\mathrm{SM}_{5}$} \\
\hline & A. glutinosa & P. nigra & F. excelsior & A. glutinosa & P. nigra & F. excelsior \\
\hline 2011 Summer & $17.51 \pm 1.07(A B)$ & $18.11 \pm 1.09(A)$ & $17.04 \pm 1.73(B)$ & $27.24 \pm 4.67(\mathrm{~A})$ & $26.22 \pm 2.65(\mathrm{~A})$ & $26.45 \pm 2.42(\mathrm{~A})$ \\
\hline 2012 Winter & $2.02 \pm 2.00(\mathrm{~A})$ & $3.00 \pm 2.49(\mathrm{~A})$ & $2.05 \pm 4.17(\mathrm{~A})$ & $31.24 \pm 3.42(A B)$ & $29.36 \pm 2.76(A)$ & $32.46 \pm 4.37(B)$ \\
\hline 2012 Spring & $18.16 \pm 0.84(\mathrm{~A})$ & $18.53 \pm 0.64(\mathrm{~A})$ & $18.57 \pm 1.48(\mathrm{~A})$ & $16.19 \pm 2.80(A)$ & $14.15 \pm 1.26(B)$ & $17.86 \pm 2.16(A)$ \\
\hline 2012 Summer & $19.74 \pm 1.69(A)$ & $22.15 \pm 3.11(B)$ & $19.57 \pm 2.07(A)$ & $13.04 \pm 2.55(\mathrm{~A})$ & $12.93 \pm 3.65(\mathrm{~A})$ & $12.87 \pm 2.60(\mathrm{~A})$ \\
\hline \multirow{2}{*}{2012 Autumn } & \multicolumn{3}{|c|}{$\mathrm{SM}_{30}$} & \multicolumn{3}{|c|}{$\mathrm{SR}_{\text {tot }}$} \\
\hline & L1 & $\mathrm{L} 2$ & L3 & A. glutinosa & P. nigra & F. excelsior \\
\hline 2011 Summer & $42.49 \pm 0.45(A)$ & $22.22 \pm 0.23(B)$ & $12.60 \pm 0.36(C)$ & $1.24 \pm 0.28(\mathrm{~A})$ & $1.42 \pm 0.33(\mathrm{~A})$ & $1.26 \pm 0.20(A)$ \\
\hline 2011 Autumn & $42.92 \pm 3.52(A)$ & $28.69 \pm 2.20(B)$ & $22.31 \pm 3.32(C)$ & $0.69 \pm 0.27(A B)$ & $0.89 \pm 0.22(B)$ & $0.80 \pm 0.04(A)$ \\
\hline 2012 Winter & $46.08 \pm 0.11(A)$ & $27.35 \pm 0.22(B)$ & $18.61 \pm 0.18(C)$ & $1.44 \pm 0.08(\mathrm{~A})$ & $0.28 \pm 0.08(\mathrm{~A})$ & $0.26 \pm 0.04(B)$ \\
\hline
\end{tabular}


Acknowledgements. We gratefully acknowledge the help of Elisenda Sánchez, Callum Berridge, Daniel Nadal, Anna Lupón and Abdellah Boumghar for their assistance during field work and experiment implementation. The research leading to these results has received funding from the European Community's Seventh Framework Programme GREENCYCLESII (FP7 2007-2013) under grant agreement no. 238366, MEDFORESTREAM (CGL2011-30590-C02-01) and MONTES-Consolider (CSD200800040).

Edited by: A. J. Dolman

\section{References}

Almagro, M., López, J., Querejeta, J. I., and Martínez-Mena, M.: Temperature dependence of soil $\mathrm{CO}_{2}$ efflux is strongly modulated by seasonal patterns of moisture availability in a Mediterranean ecosystem, Soil Biol. Biochem., 41, 594-605, 2009.

Bowden, R. D., Newkirk, K. M., and Rullo, G. M.: Carbon dioxide and methane fluxes by a forest soil under laboratory-controlled moisture and temperature conditions, Soil Biol. Biochem., 30, 1591-1597, 1998.

Bowling, D. R., Grote, E. E., and Belnap, J.: Rain pulse response of soil $\mathrm{CO}_{2}$ exchange by biological soil crusts and grasslands of the semiarid Colorado Plateau, United States, J. Geophys. Res., 116, G03028, doi:10.1029/2011JG001643, 2011.

Casals, P., Lopez-Sangil, L., Carrara, A., Gimeno, C., and Nogués, S.: Autotrophic and heterotrophic contributions to shortterm soil $\mathrm{CO}_{2}$ efflux following simulated summer precipitation pulses in a Mediterranean dehesa, Global Biogeochem. Cy., 25, GB3012, doi:10.1029/2010GB003973, 2011.

Cisneros-Dozal, L. M., Trumbore, S. E., and Hanson, P. J.: Effect of moisture on leaf litter decomposition and its contribution to soil respiration in a temperate forest, J. Geophys. Res., 112, G01013, doi:10.1029/2006JG000197, 2007.

Comstedt, D., Boström, B., and Ekblad, A.: Autotrophic and heterotrophic soil respiration in a Norway spruce forest: estimating the root decomposition and soil moisture effects in a trenching experiment, Biogeochemistry, 104, 121-132, 2010.

Conant, R. T., Dalla-Betta, P., Klopatek, C. C., and Klopatek, J. M.: Controls on soil respiration in semiarid soils, Soil Biol. Biochem., 36, 945-951, 2004.

Curiel-Yuste, J., Janssens, I. A., Carrara, A., Meiresonne, L., and Ceulemans, R.: Interactive effects of temperature and precipitation on soil respiration in a temperate maritime pine forest, Tree Physiol., 23, 1263-70, 2003.

Curiel-Yuste, J., Janssens,I.A., Carrara,A., and Ceulemans,R.: Annual Q10 of soil respiration reflects plant phenological patterns as well as temperature sensitivity, Glob. Change Biol., 10, 161-169, 2004.

Curiel-Yuste, J., Baldocchi, D. D., Gershenson, A., Goldstein, A., Misson, L., and Wong, S.: Microbial soil respiration and its dependency on carbon inputs, soil temperature and moisture, Glob. Change Biol., 13, 2018-2035, 2007.

Davidson, E., Belk, E., and Boone, R. D.: Soil water content and temperature as independent or confounded factors controlling soil respiration in a temperate mixed hardwood forest, Glob. Change Biol., 4, 217-227, 1998.
Davidson, E. A., Janssens, I. A., and Luo, Y.: On the variability of respiration in terrestrial ecosystems: moving beyond $Q_{10}$, Glob. Change Biol., 12, 154-164, 2006.

Epron, D., Farque, L., Lucot, É., and Badot, P.-M.: Soil $\mathrm{CO}_{2}$ efflux in a beech forest: dependence on soil temperature and soil water content, Ann. For. Sci., 56, 221-226, 1999.

Epron, D., Le Dantec, V., Dufrene, E., and Granier, A.: Seasonal dynamics of soil carbon dioxide efflux and simulated rhizosphere respiration in a beech forest, Tree Physiol., 21, 145-52, 2001.

Fang, C. and Moncrieff, J. B.: The dependence of soil $\mathrm{CO}_{2}$ efflux on temperature, Soil Biol. Biochem., 33, 155-165, 2001.

Fang, C., Smith, P., Moncrieff, J. B., and Smith, J. U.: Similar response of labile and resistant soil organic matter pools to changes in temperature, Nature, 433, 57-59, 2005.

Gärdenäs, A. I.: Soil respiration fluxes measured along a hydrological gradient in a Norway spruce stand in south Sweden (Skogaby), Plant Soil, 221, 273-280, 2000.

Gaumont-Guay, D., Black, T. A., Griffis, T. J., Barr, A. G., Jassal, R. S., and Nesic, Z.: Interpreting the dependence of soil respiration on soil temperature and water content in a boreal aspen stand, Agr. Forest Meteorol., 140, 220-235, 2006.

Hanson, P. J., Edwards, N. T., Garten, C. T., and Andrews, J. A.: Separating root and soil microbial contributions to soil respiration: a review of methods and observations, Biogeochemistry, 48, 115-146, 2000.

Häring, T., Reger, B., Ewald, J., Hothorn, T., and Schröder, B.: Predicting Ellenberg's soil moisture indicator value in the Bavarian Alps using additive georegression, Appl. Veg. Sci., 16, 110-121, 2013.

Heinemeyer, A., Hartley, I. P., Evans, S. P., Carreira De La Fuente, J. A., and Ineson, P.: Forest soil $\mathrm{CO}_{2}$ flux: uncovering the contribution and environmental responses of ectomycorrhizas, Glob. Change Biol., 13, 1786-1797, 2007.

Hogberg, P., Nordgren, A., Buchmann, N., Taylor, A. F. S., Ekblad, A., Hogberg, M. N., Nyberg, G., Ottosson-Lofvenius, M., and Read, D. J.: Large-scale forest girdling shows that current photosynthesis drives soil respiration, Nature, 411, 789-792, 2001.

Jassal, R. S., Black, T. A., Novak, M. D., Gaumont-Guay, D., and Nesic, Z.: Effect of soil water stress on soil respiration and its temperature sensitivity in an 18-year-old temperate Douglas-fir stand, Glob. Change Biol., 14, 1305-1318, 2008.

Jobbágy, E. G. and Jackson, R. B.: The vertical distribution of soil organic carbon and its relation to climate and vegetation, Ecol. Appl., 10, 423-436, 2000.

Keith, H., Jacobsen, K. L., and Raison, R. J.: Effects of soil phosphorus availability, temperature and moisture on soil respiration in Eucalyptus pauciflora forest, Plant Soil, 190, 127-141, 1997.

Knorr, W., Prentice, I. C., House, J. I., and Holland, E. A.: Longterm sensitivity of soil carbon turnover to warming, Nature, 433, 298-301, 2005.

Kuzyakov, Y. V. and Larionova, A. A.: Contribution of rhizomicrobial and root respiration to the $\mathrm{CO}_{2}$ emission from soil (a review), Eurasian Soil Sci.+, 39, 753-764, 2006.

Lee, X., Wu, H.-J., Sigler, J., Oishi, C., Siccama, T., and Haven, N.: Rapid and transient response of soil respiration to rain, Glob. Change Biol., 10, 1017-1026, 2004.

Lellei-Kovács, E., Kovács-Láng, E., Botta-Dukát, Z., Kalapos, T., Emmett, B., and Beier, C.: Thresholds and interactive effects 
of soil moisture on the temperature response of soil respiration, Eur. J. Soil Biol., 47, 247-255, 2011.

Lloyd, J. and Taylor, J. A.: On the temperature dependence of soil respiration, Funct. Ecol., 8, 315-323, 1994.

Londo, A. J., Messina, M. G., and Schoenholtz, S. H.: Forest Harvesting Effects on Soil Temperature, Moisture, and Respiration in a Bottomland Hardwood Forest, Soil Sci. Soc. Am. J., 63, 637-644, 1999.

Martin, J. G. and Bolstad, P. V.: Annual soil respiration in broadleaf forests of northern Wisconsin: influence of moisture and site biological, chemical, and physical characteristics, Biogeochemistry, 73, 149-182, 2005.

McGlynn, B. L. and Seibert, J.: Distributed assessment of contributing area and riparian buffering along stream networks, Water Resour. Res., 39, 1082, doi:10.1029/2002WR001521, 2003.

Mielnick, P. C. and Dugas, W. A.: Soil $\mathrm{CO}_{2}$ flux in a tallgrass prairie, Soil Biol. Biochem., 32, 221-228, 2000.

Nordgren, A., Löfvenius, M. O., Högberg, M. N., and Mellander, P.: Tree root and soil heterotrophic respiration as revealed by girdling of boreal Scots pine forest?: Extending observations, Environment, 26, 1287-1296, 2003.

Orchard, V. A. and Cook, F. J.: Relationship between soil respiration and soil moisture, Soil Biol. Biochem., 15, 447-453, 1983.

Pacific, V. J., McGlynn, B. L., Riveros-Iregui, D. a., Welsch, D. L., and Epstein, H. E.: Variability in soil respiration across riparianhillslope transitions, Biogeochemistry, 91, 51-70, 2008.

Palmroth, S., Maier, C. A., McCarthy, H. R., Oishi, A. C., Kim, H.S., Johnsen, K. H., Katul, G. G., and Oren, R.: Contrasting responses to drought of forest floor $\mathrm{CO}_{2}$ efflux in a loblolly pine plantation and a nearby oak-hickory forest, Glob. Change Biol., 11, 421-434, 2005.

Raich, J. W. and Potter, C. S.: Global patterns of carbon dioxide emissions from soils, Global Biogeochem. Cy., 9, 23-36, 1995.

Raich, J. W. and Tufekcioglu, A.: Vegetation and soil respiration?: Correlations and controls, Biogeochemistry, 48, 71-90, 2000.

Raich, J. W., Potter, C. S., and Bhagawati, D.: Interannual variability in global soil respiration, 1980-1994, Glob. Change Biol., 8, 800-812, 2002.

Rey, A., Pegoraro, E., Tedeschi, V., De Parri, I., Jarvis, P. G., and Valentini, R.: Annual variation in soil respiration and its components in a coppice oak forest in Central Italy, Glob. Change Biol., 8, 851-866, 2002.

Rustad, L. E., Huntington, T. G., and Boone, D.: Controls on soil respiration?: Implications for climate change, Biogeochemistry, 48, 1-6, 2000.

Schimel, D. S., House, J. I., Hibbard, K. A., Bousquet, P., Ciais, P., Peylin, P., Braswell, B. H., Apps, M. J., Baker, D., Bondeau, A., Canadell, J., Churkina, G., Cramer, W., Denning, A. S., Field, C. B., Friedlingstein, P., Goodale, C., Heimann, M., Houghton, R. A., Melillo, J. M., Moore, B., Murdiyarso, D., Noble, I., Pacala, S. W., Prentice, I. C., Raupach, M. R., Rayner, P. J., Scholes, R. J., Steffen, W. L., and Wirth, C.: Recent patterns and mechanisms of carbon exchange by terrestrial ecosystems, Nature, 414, 169-72, 2001.
Schlesinger, W. H. and Andrews, J. A.: Soil respiration and the global carbon cycle, Biogeochemistry, 48, 7-20, 2000.

Sjögersten, S., van der Wal, R., and Woodin, S. J.: Small-scale hydrological variation determines landscape $\mathrm{CO}_{2}$ fluxes in the high Arctic, Biogeochemistry, 80, 205-216, 2006.

Skopp, J., Jawson, M. D., and Doran, J. W.: Steady-State Aerobic Microbial Activity as a Function of Soil Water Content, Soil Sci. Soc. Am. J., 54, 1619-1625, 1990.

Unger, S., Máguas, C., Pereira, J. S., David, T. S., and Werner, C.: The influence of precipitation pulses on soil respiration - assessing the "Birch effect" by stable carbon isotopes, Soil Biol. Biochem., 42, 1800-1810, 2010.

van 't Hoff, J. H.: Lectures on Theoretical and Physical Chemistry, Edward Arnold, 1898.

Wang, B., Zha, T. S., Jia, X., Wu, B., Zhang, Y. Q., and Qin, S. G.: Soil moisture modifies the response of soil respiration to temperature in a desert shrub ecosystem, Biogeosciences Discuss., 10, 9213-9242, doi:10.5194/bgd-10-9213-2013, 2013.

Wang, Y., Wang, Z.-L., Wang, H., Guo, C., and Bao, W.: Rainfall pulse primarily drives litterfall respiration and its contribution to soil respiration in a young exotic pine plantation in subtropical China, Can. J. Forest Res., 42, 657-666, 2012.

Wardle, D.: A. Communities and ecosystems: linking the aboveground and belowground components, Vol. 34, Princeton University Press, 2002.

Welsch, D. L. and Hornberger, G. M.: Spatial and temporal simulation of soil $\mathrm{CO}_{2}$ concentrations in a small forested catchment in Virginia, Biogeochemistry, 71, 413-434, 2004.

Wen, X.-F., Yu, G.-R., Sun, X.-M., Li, Q.-K., Liu, Y.-F., Zhang, L.M., Ren, C.-Y., Fu, Y.-L., and Li, Z.-Q.: Soil moisture effect on the temperature dependence of ecosystem respiration in a subtropical Pinus plantation of southeastern China, Agr. Forest Meteorol., 137, 166-175, 2006.

Xu, J., Chen, J., Brosofske, K., Li, Q., Weintraub, M., Henderson, R., Wilske, B., John, R., Jensen, R., Li, H., and others: Influence of timber harvesting alternatives on forest soil respiration and its biophysical regulatory factors over a 5-year period in the Missouri Ozarks, Ecosystems, 14, 1310-1327, 2011.

$\mathrm{Xu}, \mathrm{M}$. and Qi, Y.: Soil-surface $\mathrm{CO}_{2}$ efflux and its spatial and temporal variations in a young ponderosa pine plantation in northern California, Glob. Change Biol., 7, 667-677, 2001.

Yan, L., Chen, S., Huang, J., and Lin, G.: Differential responses of auto-and heterotrophic soil respiration to water and nitrogen addition in a semiarid temperate steppe, Glob. Change Biol., 16, 2345-2357, 2010.

Zanchi, F. B., Waterloo, M. J., Dolman, A. J., Groenendijk, M., Kesselmeier, J., Kruijt, B., Bolson, M. A., Luizão, F. J., and Manzi, A. O.: Influence of drainage status on soil and water chemistry, litter decomposition and soil respiration in central Amazonian forests on sandy soils, Rev. Ambient. e Água, 6, 6-29, 2011.

Zeileis, A., Hothorn, T., and Hornik, K.: Model-based recursive partitioning, J. Comput. Graph. Stat., 17, 492-514, 2008. 